\title{
Entomopathogenic nematodes for the control of phorid and sciarid flies in mushroom crops
}

\author{
María Jesús Navarro(1) and Francisco José Gea(1)
} ${ }^{(1)}$ Centro de Investigación, Experimentación y Servicios del Champiñón, c/ Peñicas, s/no, 16220, Quintanar del Rey, Cuenca, Spain.
E-mail: mjnavarro.cies@dipucuenca.es, fjgea.cies@dipucuenca.es

\begin{abstract}
The objective of this work was to evaluate the efficacy of two nematodes, Steinernema feltiae and S. carpocapsae, to control mushroom flies and to evaluate the effect of these treatments on Agaricus bisporus production. Two mushroom cultivation trials were carried out in controlled conditions, in substrate previously infested with the diptera Megaselia halterata and Lycoriella auripila, with two treatments: $10^{6}$ infective juveniles (IJ) per square meter of S. feltiae and $0.5 \times 10^{6} \mathrm{IJ} \mathrm{m}^{-2} S$. feltiae $+0.5 \times 10^{6} \mathrm{IJ} \mathrm{m}^{-2}$ S. carpocapsae. Another experiment was carried out using the same treatments to evaluate the possible nematode effect on mushroom yield. The number of adults emerging from the substrate was evaluated for each fly species. No decrease in the population of $M$. halterata was detected with nematode application, whereas the number of L. auripila was reduced in both treatments, particularly in the individual treatment with $S$. feltiae. The application of entomopathogenic nematodes has no adverse effect on mushroom production.
\end{abstract}

Index terms: Agaricus bisporus, Lycoriella auripila, Megaselia halterata, Steinernema carpocapsae, Steinernema feltiae, biological control.

\section{Nematoides entomopatogênicos no controle de moscas Phoridae e Sciaridae em cultivo de cogumelos}

Resumo - O objetivo deste trabalho foi avaliar a eficiência de dois nematoides, Steinernema feltiae e S. carpocapsae, no controle de moscas dos cogumelos e avaliar o efeito desses tratamentos na produção de Agaricus bisporus. Foram realizados dois ensaios de cultivo de cogumelos em condições controladas, em substrato previamente infestado pelos dípteros Megaselia halterata e Lycoriella auripila, com dois tratamentos: $10^{6}$ juvenis infectantes (IJ) por metro quadrado de $S$. feltiae e $0,5 \times 10^{6} \mathrm{IJ} \mathrm{m}^{-2}$ de $S$. feltiae $+0,5 \times 10^{6} \mathrm{IJ} \mathrm{m}^{-2} \mathrm{de}$ $S$. carpocapsae. Foi realizado outro experimento, com uso dos mesmos tratamentos, para avaliar o possível efeito dos nematoides sobre a produção dos cogumelos. Avaliou-se o número de adultos que emergiram no substrato, para cada espécie de mosca. Não foi detectada redução da população de $M$. halterata com a aplicação de nematoides, enquanto o número de L. auripila foi reduzido em ambos os tratamentos, particularmente no tratamento individual com $S$. feltiae. A aplicação de nematoides entomopatogênicos não tem efeito adverso na produção de cogumelos.

Termos para indexação: Agaricus bisporus, Lycoriella auripila, Megaselia halterata, Steinernema carpocapsae, Steinernema feltiae, controle biológico.

\section{Introduction}

The phorid Megaselia halterata (Wood) and the sciarid Lycoriella auripila Winnertz are common pests in mushroom farms of Castilla-La Mancha, Spain (Navarro et al., 2002). In their larval stage, these flies feed on mushroom mycelia and even burrow into mushrooms once they are formed (Shamshad, 2010); as adults, they act as vectors of other pests and diseases (Clift et al., 2004; Navarro Lozano et al., 2004; Shamshad et al., 2009; Shamshad, 2010). Unlike in other European countries, where sciarids are present throughout the year and phorids undergo a period of hibernation (Jess et al., 2007), in Spain M. halterata populations are present in high numbers throughout the year, whereas L. auripila is detected in much lower numbers (four times less than $M$. halterata) and almost exclusively in spring (Navarro et al., 2002).

Traditionally, flies in mushroom crops have been controlled by insecticides, although resistance to certain products has been recorded (Bartlett \& Keil, 1997; Smith, 2002). However, the application of phytosanitary products may give rise to two further problems - detrimental effects on the mushroom 
mycelium, leading to a loss of yield or quality (Grewal et al., 1992; Scheepmaker et al., 1998; Shamshad, 2010), and the presence of residues in the mushrooms once harvested (Navarro \& Gea, 2006). Other methods for controlling flies are based on the use of physical barriers to exclude adult individuals from growing in farms (Coles, 2002); on biocontrol organisms, such as mites, bacteria and entomopathogenic nematodes; and, more recently, on plant extracts (Jess \& Bingham, 2004; Shamshad et al., 2008; Erler et al., 2009a, 2009b).

Richardson (1987) was the first to use entomopathogenic nematodes of the genera Steinernema and Heterorhabditis to control mushroom flies. Steinernema spp. nematodes locate and invade fly larvae via anus, mouth or spiracles, and release bacteria associated to them (Xenorhabdus sp. or Photorhabdus sp.), which provokes the death of the infested flies (Kirk \& Keil, 2001). However, apart from their compatibility with the insecticides used (Koppenhöfer \& Grewal, 2005), the effectiveness of nematodes in mushroom culture depends on other factors such as temperature, moisture and $\mathrm{CO}_{2}$ levels, which may also affect them (Kirk \& Keil, 2001).

Information about phorid control by nematodes is scarce in the literature. According to Grewal et al. (1993), the effect of $S$. feltiae on M. halterata is not significant. However, Scheepmaker et al. (1997) found a substantial decrease in the second generation of $M$. halterata following the application of $3 \times 10^{6}$ infective juveniles (IJ) per square meter of $S$. feltiae one week after casing. More recently, Erler et al. (2009b) described the effectiveness of $S$. feltiae applied on substrates after controlled infestation with $M$. halterata. However, S. carpocapsae, applied at a dose of up to $15 \times 10^{6} \mathrm{IJ} \mathrm{m}^{-2}$ on casing soil, coinciding with the third larval instar, can reduce phorid populations by up to 73\% (Jess \& Bingham, 2004). This concentration, however, is too expensive to have any commercial appeal. For the control of sciarids with nematodes, many authors defend the use of $S$. feltiae, having observed effectiveness between 66 and $95 \%$, depending on the fly population and the timing of nematode application (Scheepmaker et al., 1997; Shamshad et al., 2008). In the case of $S$. carpocapsae, Gouge \& Hague (1995) reported the relative inefficacy of this species against sciarids, whereas other authors defend its efficacy, but with a lower infectivity than that of S. feltiae (Kim et al., 2004). Furthermore, some authors observed a detrimental effect of treatments involving entomophathogenic nematodes on mushroom mycelia, such as reduced yield in early flushes, depending on the nematode dosage rate (Grewal et al., 1992).

The objective of this work was to evaluate the efficacy of two nematodes, S. feltiae and S. carpocapsae, for control of mushroom flies and to evaluate the effect of these treatments on Agaricus bisporus production.

\section{Materials and Methods}

Two cropping trials were set up in an experimental mushroom growing room (20 $\mathrm{m}^{3}$ approximately) following the standard practices used in mushroom farms in Spain (Navarro Lozano et al., 2004). In each trial, A. bisporus (Lange) Imbach, Gurelan 45 strain, (Gurelan S. Coop., Huarte, Pamplona, Spain) was cultivated in 40 experimental trays $(16 \mathrm{~L}$ in volume, $870 \mathrm{~cm}^{2}$ in area) filled with $6 \mathrm{~kg}$ of commercial mushroom compost (Villacasa S.L., Casasimarro, Cuenca, Spain) spawned at $0.9 \%$. Spawn run took place for 15 days at $26^{\circ} \mathrm{C}$ and $95 \%$ relative humidity (RH). On day 15 , trays were cased with a $40 \mathrm{~mm}$ layer of Topterra mushroom casing (Topterra Holland, Wanssum, Netherlands), 3.5 L per tray, previously hydrated to $72-76 \%$ moisture. The environmental conditions were modified to stimulate the production of mushroom fruit bodies. A temperature of $18^{\circ} \mathrm{C}$ and RH of $85-90 \%$ were maintained throughout harvest. The trials were concluded after 50 days.

A randomized complete block design, with four treatments and ten replicates, was used in each trial. The treatments applied were: Sf, $S$. feltiae treatment, fly-infested trays and subsequent application of $10^{6} \mathrm{IJ} \mathrm{m}^{-2} \mathrm{~S}$. feltiae, Biorend R champiñones, (Idebio S.L., Salamanca, Spain) together with $1 \mathrm{~mL}$ of chitosan in $150 \mathrm{~mL}$ water per tray; $\mathrm{Sf}+\mathrm{Sc}, \mathrm{S}$. feltiae + S. carpocapsae treatment, infested trays and subsequent application of $0.5 \times 10^{6} \mathrm{IJ} \mathrm{m}^{-2} S$. feltiae $+0.5 \times 10^{6} \mathrm{IJ} \mathrm{m}^{-2}$ $S$. carpocapsae, Biorend $\mathrm{R}$ champiñones + Biorend R palmeras, (Idebio S.L., Salamanca, Spain) together with $1 \mathrm{~mL}$ of chitosan in $150 \mathrm{~mL}$ water per tray. Ten trays free of fly infestation and with no nematode application were used as non-infested controls (C), and ten fly-infested trays with no nematode application were used as infested controls (IC).

The first trial was performed to evaluate the effect of the treatments on fly control under an infection 
pressure of 800 phorids and 52 sciarids per day. On day 5 of spawn running, the trays corresponding to treatments $\mathrm{IC}, \mathrm{Sf}$, and $\mathrm{Sf}+\mathrm{Sc}$ were exposed to flies for 48 hours in a commercial mushroom growing house of $45 \mathrm{~m}^{2}$ cropping area. Then, all the trays were covered with a cubic structure $(37 \times 37 \times 37 \mathrm{~cm})$ made of anti-trip $(0.6 \mathrm{~mm})$ mesh and placed back in the experimental mushroom growing room to continue spawn running. A yellow sticky trap $(14 \times 7.5 \mathrm{~cm})$ was placed inside each of these cubic structures to capture the flies. On day 16, the different entomopathogenic nematode treatments were applied on the surface of each tray. In this way, the time elapsing between natural infestation and the application of nematodes was ten days.

The second trial was performed to evaluate the effect of the treatments on fly control under an infection pressure of 1,237 phorids and 82 sciarids per day. On day 11 of spawn running, the trays corresponding to treatments $\mathrm{IC}, \mathrm{Sf}$, and $\mathrm{Sf}+\mathrm{Sc}$ were exposed to infestation for 48 hours in a commercial mushroom growing house of $45 \mathrm{~m}^{2}$ cropping area. Subsequently, all the trays were handled as in the first trial. On day 16, the different entomopathogenic nematode treatments were applied on the surface of each tray. In this case, the time elapsing between natural infestation and the application of nematodes was four days.

To prevent the flies from escaping, harvesting of the first flush was delayed until the sticky traps had been withdrawn. The experiments were considered finished after the emergence of all the first generation adults. Then, the captured flies were counted and identified by binocular stereomicroscope. Treatments were evaluated by counting the emerged adults per tray in each treatment. The percentage reduction in adult emergence for each treatment in each of the trials was calculated by the formula: \% Reduction $=[(\mathrm{Y}-\mathrm{X}) / \mathrm{Y}]$ $\mathrm{x} 100$, in which $\mathrm{X}$ is the number of emerging adults in each of the treatments, and $\mathrm{Y}$ is the number of emerging adults in the infested control (Erler et al., 2009a).

To determine the effect of the entomopathogenic nematodes on $A$. bisporus yield, a cropping trial was set up in an experimental mushroom growing room, under the same conditions as the two previous trials but with no dipteral infestations. Two treatments and a control were also established: $\mathrm{Sf}, \mathrm{Sf}+\mathrm{Sc}$, and C. Mushrooms were harvested daily for two flushes. The number and total weight of the fruit bodies were recorded for each treatment. The effect of entomopathogenic nematodes on mushroom productivity was evaluated from the total yield of harvested mushrooms, and from the number and unitary weight of mushrooms. The effect of treatments on mushroom productivity was also evaluated from the biological efficiency of the crop, calculated as the ratio of the fresh weight of the total yield of harvested mushrooms to the weight of dry substrate at spawning, expressing the fraction as $\mathrm{kg}$ $100 \mathrm{~kg}^{-1}$ compost. In addition, the earliness of each treatment was expressed as the number of days between casing and harvesting of the first flush. This experiment was set up as a randomized complete block design with 12 replicates.

Analyses of variance, with logarithmic or square root transformation for count data and angular transformation of the percentage data to stabilize variances when necessary, were done using the software package Statgraphics Plus, version 4.1 (Statistical Graphics Corp., Princeton, NJ, USA). Tukey's test, at $5 \%$ probability, was used to establish significant differences between means.

\section{Results and Discussion}

The total number of flies captured in the first trial was lower than in the second one, reflecting the lower degree of initial infection pressure in the first trial. Although fly captures were registered in the non-infested trays (Table 1), in both trials and for both flies, the data obtained for treatment IC were significantly higher than those for $\mathrm{C}$, indicating the good progress of the infection process.

In the first trial, the mean number of emerging M. halterata was 233 for the infested control trays (IC), and 186.3 and 221.8 for the nematode treatments Sf and $\mathrm{Sf}+\mathrm{Sc}$, respectively, with no significant differences between them $\left(\mathrm{F}_{2,29}=0.63 ; \mathrm{p}=0.5415\right)$. No significant differences $\left(\mathrm{F}_{2,23}=1.21 ; \mathrm{p}=0.3168\right)$ were observed between the numbers of phorid flies captured in the treatments $\mathrm{IC}, \mathrm{Sf}$, and $\mathrm{Sf}+\mathrm{Sc}$ in the second trial (Table 1). There was also no effect of the treatments $\mathrm{Sf}$ and $\mathrm{Sf}+\mathrm{Sc}$ in the emergence of $M$. halterata adults in both trials, and no phorid percentage reduction was verified for any treatment.

The ineffectiveness of $S$. feltiae for controlling phorids agrees with most of the consulted bibliography (Grewal et al., 1993; Jess et al., 2005). However, it contrasts with the findings of Long et al. (2000) in 
laboratory bioassays. These authors reported that $S$. feltiae is effective in the control of $M$. halterata, probably because nematodes applied on growing substrates show different behavior. The results of the present work also contrast with the findings of other authors, who observed a reduction of more than $70 \%$ in the emergence of $M$. halterata adults after the application of S. feltiae (Scheepmaker et al., 1997; Erler et al., 2009b). This divergence in results was probably due to the fact that in the present study only the first generation of adults after infestation was considered, whereas the above authors also considered subsequent generations.

The ineffectiveness of the $\mathrm{Sf}+\mathrm{Sc}$ treatment on $M$. halterata was observed regardless of the trials, which contrasts with the results obtained by Jess \& Bingham (2004), who confirmed the use of $S$. carpocapsae to control phorids. This discrepancy might be due to the lower application doses used or to the application of both nematode species.

In trial conditions, the inefficacy of both treatments against $M$. halterata was independent of the time elapsing between infestation and nematode application. For optimum efficacy, nematodes should be applied when a majority of hosts are susceptible to nematode infection. In the first trial, considering the environmental conditions and the time elapsing between infestation and treatment (9-10 days), the larvae were presumed to be in a sufficiently advanced stage (third larval instar) to allow infestation by nematodes (Jess \& Bingham, 2004; Jess et al., 2005). However, not even in these favorable conditions did the applications lead to an acceptable level of reduction when the nematode formulations were used. Further efforts to develop entomopathogenic nematodes against $M$. halterata are necessary.
In the first trial, the mean number of emerging L. auripila was 136 for the infested control trays (IC), and significantly lower $\left(\mathrm{F}_{2,29}=9.42\right.$; $p=0.0007)$ for both nematode treatments. There was no significant difference between the $\mathrm{Sf}$ and $\mathrm{Sf}+\mathrm{Sc}$ treatments (Table 1). In the second trial, 184 sciarid flies were captured emerging from the infested control treatment, a value statistically similar to that recorded for the $\mathrm{Sf}+\mathrm{Sc}$ treatment; however, this number was significantly reduced $\left(\mathrm{F}_{2,23}=6.53 ; \mathrm{p}=0.0057\right)$ in the Sf treatment (116 sciarid flies). In this trial, only the $\mathrm{Sf}$ treatment reduced the adult emergence of $L$. auripila when compared to the infested control. Gouge \& Hague (1995) established that $S$. carpocapsae was relatively ineffective against different sciarid species. The results obtained in the present work are in agreement with this, but contradict those of Kim et al. (2004), who found that $S$. carpocapsae can be an effective tool for the management of the fungus gnat larvae. Both nematode species were applied together so that each could combat its own target pest. However, there was no improvement in the efficacy of the combined treatment against either fly species targeted.

For the control of sciarids (Table 1), the reduction percentage $(63 \%)$ obtained with the Sf treatment in the first trial can be considered satisfactory; however, it was less than the $80-95 \%$ reduction in sciarids obtained by other authors (Scheepmaker et al., 1997; Shamshad et al., 2008; Jess \& Schweizer, 2009). In the second trial, the reduction percentage (37\%) was significantly lower than that in the first trial $\left(F_{1,18}=9.15 ; p=0.0073\right)$. In the case of the $\mathrm{Sf}+\mathrm{Sc}$ treatment, the reduction percentage obtained in first trial $(50 \%)$ was also satisfactory and significantly higher than the one in the second trial $\left(\mathrm{F}_{1,13}=19.41\right.$; $\mathrm{p}=0.0007)$. Efficacy was lower for each treatment

Table 1. Mean numbers \pm standard error of adult Megaselia halterata and Lycoriella auripila emerging from the different trays, and the percentage reduction of $L$. auripila obtained for each treatment in both trials ${ }^{(1)}$.

\begin{tabular}{|c|c|c|c|c|c|c|}
\hline \multirow[t]{2}{*}{ Treatment } & \multicolumn{2}{|c|}{ M. halterata } & \multicolumn{2}{|c|}{ L. auripila } & \multicolumn{2}{|c|}{ L. auripila reduction $(\%)^{(2)}$} \\
\hline & First trial & Second trial & First trial & Second trial & First trial & Second trial \\
\hline $\mathrm{C}$ & $14.1 \pm 6.9 \mathrm{a}$ & $22.3 \pm 18.0 \mathrm{a}$ & $2.0 \pm 2.2 \mathrm{a}$ & $40.7 \pm 13.2 \mathrm{a}$ & - & - \\
\hline IC & $233.0 \pm 97.6 \mathrm{~b}$ & $462.7 \pm 166.2 b$ & $136.2 \pm 60.7 \mathrm{c}$ & $184.4 \pm 46.7 \mathrm{c}$ & - & - \\
\hline Sf & $186.3 \pm 57.3 \mathrm{~b}$ & $366.1 \pm 80.3 b$ & $50.3 \pm 26.2 \mathrm{~b}$ & $116.2 \pm 35.4 \mathrm{~b}$ & $63.1 \mathrm{~B}$ & $37.0 \mathrm{~A}$ \\
\hline $\mathrm{Sf}+\mathrm{Sc}$ & $221.8 \pm 121.6 \mathrm{~b}$ & $406.3 \pm 133.2 b$ & $68.1 \pm 47.4 \mathrm{~b}$ & $180.0 \pm 53.2 \mathrm{c}$ & $50.0 \mathrm{~B}$ & $2.4 \mathrm{~A}$ \\
\hline
\end{tabular}

${ }^{(1)}$ For each trial, means followed by equal letters, lowercase in the columns, do not differ significantly by Tukey's test, at $5 \%$ probability. ${ }^{(2)}$ Means followed by equal letters, uppercase in the line, do not differ significantly by Tukey's test, at $5 \%$ probability. C, non infested control; IC, infested control without nematode treatments; Sf, nematode application of $10^{6} \mathrm{IJ} \mathrm{m}^{-2}$ Steinernema feltiae; Sf+Sc, nematode application of $0.5 \times 10^{6} \mathrm{IJ} \mathrm{m}^{-2}$ S. feltiae $+0.5 \times 10^{6} \mathrm{IJ} \mathrm{m}^{-2}$ S. carpocapsae.

Pesq. agropec. bras., Brasília, v.49, n.1, p.11-17, jan. 2014

DOI: $10.1590 / \mathrm{S} 0100-204 \mathrm{X} 2014000100002$ 
in the second trial. Considering the environmental conditions and the time elapsing between infestation and treatment (3-4 days), larvae were probably not large enough to be parasitized. This agrees with the recommendation of Scheepmaker et al. (1997) to postpone treatment to a week after infestation. A longer time between infestation and nematode application would favor fly control because the nematodes would find larger larvae (third and fourth stage), which are more vulnerable to $S$. feltiae attack (Jess \& Bingham, 2004; Jess et al., 2005)

The mean values of the mushroom yields, per flush and total yield, for each of the treatments (C, Sf, and $\mathrm{Sf}+\mathrm{Sc}$ ) were statistically similar for the first flush $\left(\mathrm{F}_{2,31}=1.60 ; \mathrm{p}=0.2188\right)$, the second flush $\left(\mathrm{F}_{2,31}=2.98 ; \mathrm{p}=0.0657\right)$, and for total harvest $\left(\mathrm{F}_{2,31}=0.31 ; \mathrm{p}=0.7346\right)$; a total yield of around $20 \mathrm{~kg} \mathrm{~m}^{-2}$ was obtained in all three cases (Figure 1). This result reflects the statistically similar biological efficiency $\left(\mathrm{F}_{2,31}=0.31 ; \mathrm{p}=0.7343\right)$ of all the treatments, with values close to $85 \mathrm{~kg}$ of mushrooms per $100 \mathrm{~kg}$ of compost (dry weight) collected over two flushes (Table 2).

Regarding the number of mushrooms harvested, both treatments showed lower numbers than the control in the first flush. In the $\mathrm{Sf}+\mathrm{Sc}$ treatment this decrease

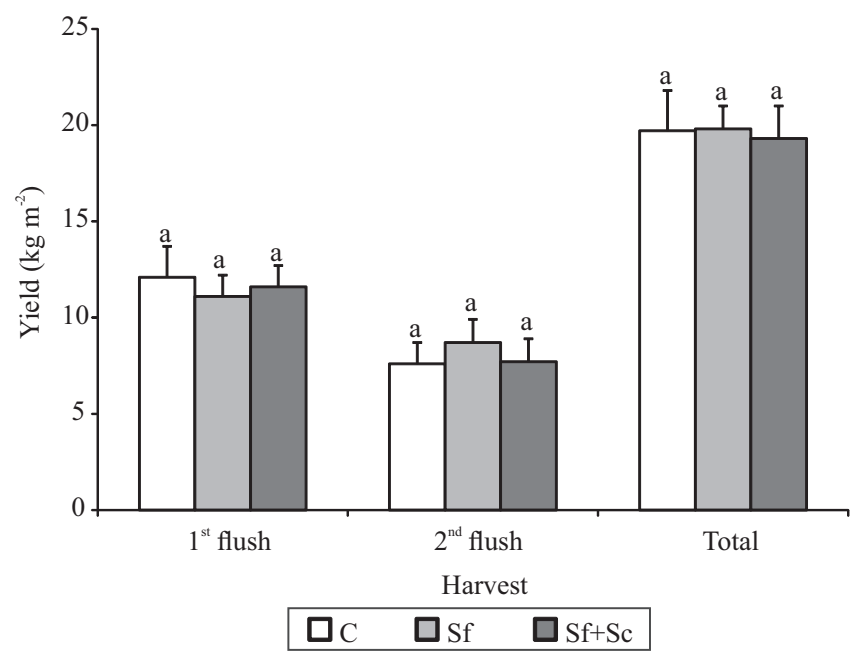

Figure 1. Mushroom yield, expressed per flush and total yield, for each of the treatments evaluated. C, control; Sf, trays with nematode application of $10^{6} \mathrm{IJ} \mathrm{m}^{-2}$ Steinernema feltiae; $\mathrm{Sf}+\mathrm{Sc}$, trays with nematode application of $0.5 \times 10^{6}$ $\mathrm{IJ} \mathrm{m}^{-2} S$. feltiae $+0.5 \times 10^{6} \mathrm{IJ} \mathrm{m}^{-2} S$. carpocapsae. For each harvest, means followed by equal letters do not differ significantly by Tukey's test, at 5\% probability. was compensated in the second flush since the total results for total yield only showed a significant drop $\left(F_{2,31}=5.28 ; p=0.0107\right)$ for the Sf treatment (Figure 2). Moreover, the unitary weight of the mushrooms was significantly higher $\left(\mathrm{F}_{2,31}=10.27 ; \mathrm{p}=0.0001\right)$ for the $\mathrm{Sf}$ treatment than for the control and for $\mathrm{Sf}+\mathrm{Sc}$ (Table 2). Lastly, earliness, defined as the time between applying the casing mixture and the first flush, varied between 21.5 and 21.7 days, with no significant differences $\left(F_{2,31}=0.28 ; p=0.7577\right)$ between treatments.

Some authors maintain that the use of entomopathogenic nematodes affects mycelial growth, depending on the nematode dosage rate (Grewal et al., 1992), leading to decreased yields for the first flush, although subsequent flushes typically compensate

Table 2. Biological efficiency ( $\mathrm{kg}$ of mushroom per $100 \mathrm{~kg}$ of dried compost), unitary weight, and earliness (days to first flush harvest) $)^{(1)}$.

\begin{tabular}{lccc}
\hline Treatments & Biological efficiency & Unitary weight & Earliness \\
\hline $\mathrm{C}$ & $84.8 \mathrm{a}$ & $12.5 \mathrm{a}$ & $21.5 \mathrm{a}$ \\
$\mathrm{Sf}$ & $85.3 \mathrm{a}$ & $15.4 \mathrm{~b}$ & $21.6 \mathrm{a}$ \\
$\mathrm{Sf}+\mathrm{Sc}$ & $83.0 \mathrm{a}$ & $12.7 \mathrm{a}$ & $21.7 \mathrm{a}$ \\
\hline
\end{tabular}

(1)Means followed by equal letters, in the columns, do not differ significantly by Tukey's test, at $5 \%$ probability. C, non-infested control; Sf, nematode application of $10^{6} \mathrm{IJ} \mathrm{m}^{-2}$ Steinernema feltiae; $\mathrm{Sf}+\mathrm{Sc}$, nematode application of $0.5 \times 10^{6} \mathrm{IJ} \mathrm{m}^{-2} \mathrm{~S}$. feltiae $+0.5 \times 10^{6} \mathrm{IJ} \mathrm{m}^{-2} \mathrm{~S}$. carpocapsae.

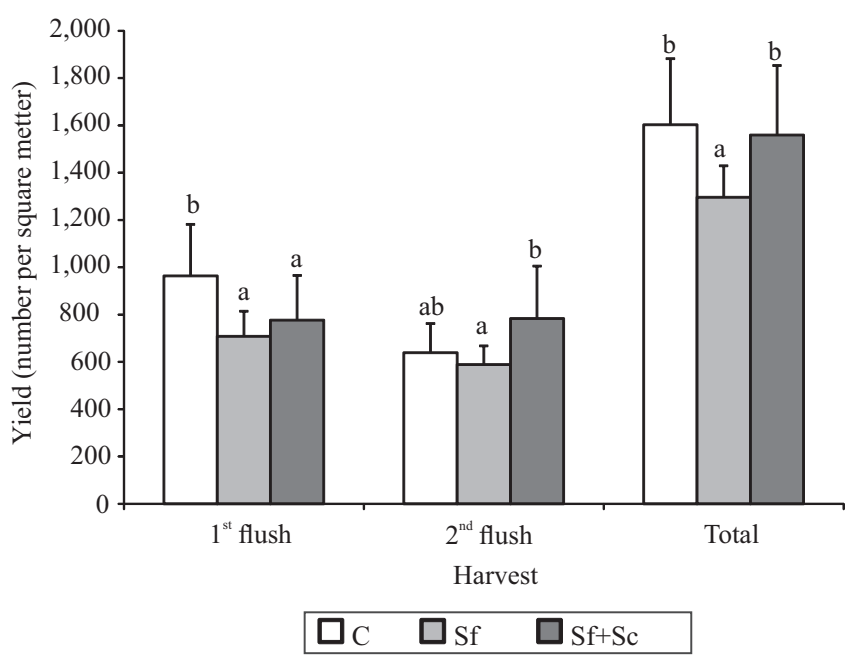

Figure 2. Mushroom yield, expressed per flush and total yield, for each of the treatments evaluated. C, control; Sf, trays with nematode application of $10^{6} \mathrm{IJ} \mathrm{m}^{-2}$ Steinernema feltiae; $\mathrm{Sf}+\mathrm{Sc}$, trays with nematode application of $0.5 \times 10^{6} \mathrm{IJ} \mathrm{m}^{-2} \mathrm{~S}$. feltiae $+0.5 \times 10^{6} \mathrm{IJ} \mathrm{m}^{-2} S$. carpocapsae. For each harvest, means followed by equal letters do not differ significantly by Tukey's test, at $5 \%$ probability. 
for this early yield loss (Jess et al., 2005). The results found in the present work contradict this affirmation since the overall yields were similar in both flushes for all treatments. For the number of carpophores collected, Grewal et al. (1992) obtained 20\% more mushrooms after the application of $S$. feltiae, which was attributed to the increased dispersion of the bacterium Pseudomonas putida, responsible for the formation of primordia in the casing material. In the present study, the application of $S$. feltiae alone reduced the number of mushrooms harvested, but the weight of individual sporophores was higher, which might be considered advantageous for better maintaining post-harvest quality, especially in the first flush when there are normally too many mushrooms to pick (Scheepmaker et al., 1998).

\section{Conclusions}

1. The application of entomopathogenic nematodes has no adverse effect on mushroom production.

2. The application of Steinernema feltiae ten days after the foreseen time of infestation is beneficial for the control of sciarids.

3. The application of $S$. feltiae, alone or with $S$. carpocapsae, has no effect on the phorids found in mushroom crops.

\section{References}

BARTLETT, G.R.; KEIL, C.B.O. Identification and characterization of a permethrin resistance mechanism in populations of the fungus gnat Lycoriella mali (Fitch) (Diptera: Sciaridae). Pesticide Biochemistry and Physiology, v.58, p.173-181, 1997. DOI: 10.1006/pest.1997.2306.

CLIFT, A.; SHAMSHAD, A.; TERRAS, M.A. Flies and dry bubble on cultivated mushrooms. In: ROMAINE, C.P.; KEIL, C.B.; RINKER, D.L.; ROYSE, D.J. (Ed.). Science and cultivation of the edible and medicinal fungi. State College: The Pennsylvania State University, 2004. p.459-464.

COLES, P. Integrated pest management in mushroom production: specific control techniques: exclusion. In: MUSHROOM integrated pest management. State College: The Pennsylvania State University, 2002. p.21-26.

ERLER, F.; POLAT, E.; DEMIR, H.; CETIN, H.; ERDEMIR, T. Control of the mushroom phorid fly, Megaselia halterata (Wood), with plant extracts. Pest Management Science, v.65, p.144-149, 2009a. DOI: $10.1002 /$ ps.1658.

ERLER, F.; POLAT, E.; DEMIR, H.; CETIN, H.; ERDEMIR, T. Evaluation of microbial products for the control of the mushroom phorid fly, Megaselia halterata (Wood). Journal of Entomological Science, v.44, p.89-97, 2009b.
GOUGE, D.H.; HAGUE, N.G.M. The susceptibility of different species of sciarid flies to entomopathogenic nematodes. Journal of Helminthology, v.69, p.313-318, 1995. DOI: 10.1017/ S0022149X00014887.

GREWAL, P.S.; RICHARDSON, P.N.; COLLINS, G.; EDMONDSON, R.N. Comparative effects of Steinernema feltiae (Nematoda: Steinernematidae) and insecticides on yield and cropping of the mushroom Agaricus bisporus. Annals of Applied Biology, v.121, p.511-520, 1992. DOI: 10.1111/j.1744-7348.1992. tb03461.x.

GREWAL, P.S.; TOMALAK, M.; KEIL, C.B.O.; GAUGLER, R. Evaluation of a genetically selected strain of Steinernema feltiae against the mushroom sciarid Lycoriella mali. Annals of Applied Biology, v.123, p.695-702, 1993. DOI: 10.1111/j.1744-7348.1993. tb04939.x.

JESS, S.; BINGHAM, J.F.W. Biological control of sciarid and phorid pests of mushroom with predatory mites from the genus Hypoaspis (Acari: Hypoaspidae) and the entomopathogenic nematode Steinernema feltiae. Bulletin of Entomological Research, v.94, p.159-167, 2004. DOI: 10.1079/BER2003286.

JESS, S.; MURCHIE, A.K.; BINGHAM, J.F.W. Potential sources of sciarid and phorid infestations and implications for centralised phases I and II mushroom compost production. Crop Protection, v.26, p.455-464, 2007. DOI: 10.1016/j.cropro.2006.04.015.

JESS, S.; SCHWEIZER, H. Biological control of Lycoriella ingenua (Diptera: Sciaridae) in commercial mushroom (Agaricus bisporus) cultivation: a comparison between Hypoaspis miles and Steinernema feltiae. Pest Management Science, v.65, p.1195-1200, 2009. DOI: 10.1002/ps.1809.

JESS, S.; SCHWEIZER, H.; KILPATRICK, M. Mushroom applications.In:GREWAL,P.S.;EHLERS, R.-U.;SHAPIRO-ILAN, D.I. (Ed.). Nematodes as biocontrol agents. New York: CABI Publishing, 2005. p.191-213. DOI: 10.1079/9780851990170.0191.

KIM, H.H.; CHOO, H.Y.; KAYA, H.K.; LEE, D.W.; LEE, S.M.; JEON, H.Y. Steinernema carpocapsae (Rhabditida: Steinernematidae) as a biological control agent against the fungus gnat Bradysia agrestis (Diptera: Sciaridae) in propagation houses. Biocontrol Science and Technology, v.14, p.171-183, 2004. DOI: 10.1080/09583150310001655693.

KIRK, D.J.; KEIL, C.B. Factors influencing efficacy of two entomopathogenic nematodes used for fly control in commercial mushroom crops. Mushroom News, v.49, p.4-17, 2001.

KOPPENHÖFER, A.M.; GREWAL, P.S. Compatibility and interactions with agrochemicals and other biocontrol agents. In: GREWAL, P.S.; EHLERS, R.-U.; SHAPIRO-ILAN, D.I. (Ed.). Nematodes as biocontrol agents. New York: CABI Publishing, 2005. p.363-381. DOI: 10.1079/9780851990170.0363.

LONG, S.J.; RICHARDSON, P.N.; WILLMOTT, D.M.; EDMONTON, R.N. Infectivity of entomopathogenic nematodes (Steinernematidae, Heterorhabditidae) to mushroom phorid fly (Megaselia halterata) larvae. Nematology, v.2, p.451-459, 2000. DOI: $10.1163 / 156854100509312$.

NAVARRO, M.J.; ESCUDERO, A.; FERRAGUT, F.; GEA, F.J. Evolution and seasonal abundance of phorid and sciarid filies in Spanish mushroom crops. In: SÁNCHEZ, J.E.; HUERTA, 
G.; MONTIEL, E. (Ed.). Mushroom biology and mushroom products. Jalisco: Universidad Autónoma del Estado de México, 2002. p.189-195.

NAVARRO, M.J.; GEA, F.J. Estudio de la fitotoxicidad del insecticida diflubenzuron en el cultivo de champiñón. Determinación del nivel de residuos. Boletín de la Asociación Española de Cultivadores de Champiñón, v.48, p.32-34, 2006.

NAVARRO LOZANO, M.J.; GEA ALEGRÍA, F.J.; FERRAGUT PÉREZ, F. Biología y control del ácaro miceliófago Brennandania lambi (Krczal) en los cultivos de champiñón de Castilla-La Mancha. Madrid: Ministerio de Agricultura, Pesca y Alimentación, 2004. 203p.

RICHARDSON, P.N. Susceptibility of mushroom pests to the insect-parasitic nematode Steinernema feltiae and Heterorhabditis heliothidis. Annals of Applied Biology, v.111, p.433-438, 1987. DOI: 10.1111/j.1744-7348.1987.tb01471.x.

SCHEEPMAKER, J.W.A.; GEELS, F.P.; RUTJENS, A.J.; SMITS, P.H.; VAN GRIENSVEN, L.J.L.D. Influence of Steinernema feltiae and diflubenzuron on yield and economics of the cultivated mushroom Agaricus bisporus in Dutch mushroom culture. Biocontrol Science and Technology, v.8, p.269-275, 1998. DOI: 10.1080/09583159830333.
SCHEEPMAKER, J.W.A.; GEELS, F.P.; SMITS, P.H.; VAN GRIENSVEN, L.J.L.D. Control of the mushroom pests Lycoriella auripila (Diptera: Sciaridae) and Megaselia halterata (Diptera: Phoridae) by Steinernema feltiae (Nematoda: Steinernematidae) in field experiments. Annals of Applied Biology, v.131, p.359-368, 1997. DOI: 10.1111/j.1744-7348.1997.tb05165.x.

SHAMSHAD, A. The development of integrated pest management for the control of mushroom sciarid flies, Lycoriella ingenua (Dufour) and Bradysia ocellaris (Comstock), in cultivated mushrooms. Pest Management Science, v.66, p.1063-1074, 2010. DOI: $10.1002 /$ ps.1987.

SHAMSHAD, A.; CLIFT, A.D.; MANSFIELD, S. Toxicity of six commercially formulated insecticides and biopesticides to third instar larvae of mushroom sciarid, Lycoriella ingenua Dufour (Diptera: Sciaridae), in New South Wales, Australia. Australian Journal of Entomology, v.47, p.256-260, 2008. DOI: 10.1111/j.1 440-6055.2008.00653.x.

SHAMSHAD, A.; CLIFT, A.D.; MANSFIELD, S. The effect of tibia morphology on vector competency of mushroom sciarid flies. Journal of Applied Entomology, v.133, p.484-490, 2009. DOI: 10.1111/j.1439-0418.2008.01362.x.

SMITH, J.E. Dimilin resistance in mushroom sciarids. The Mushroom Journal, v.626, p.15, 2002.

Received on July 31, 2013 and accepted on December 27, 2013 